Current Perspectives in Psychology 
This page intentionally left blank 

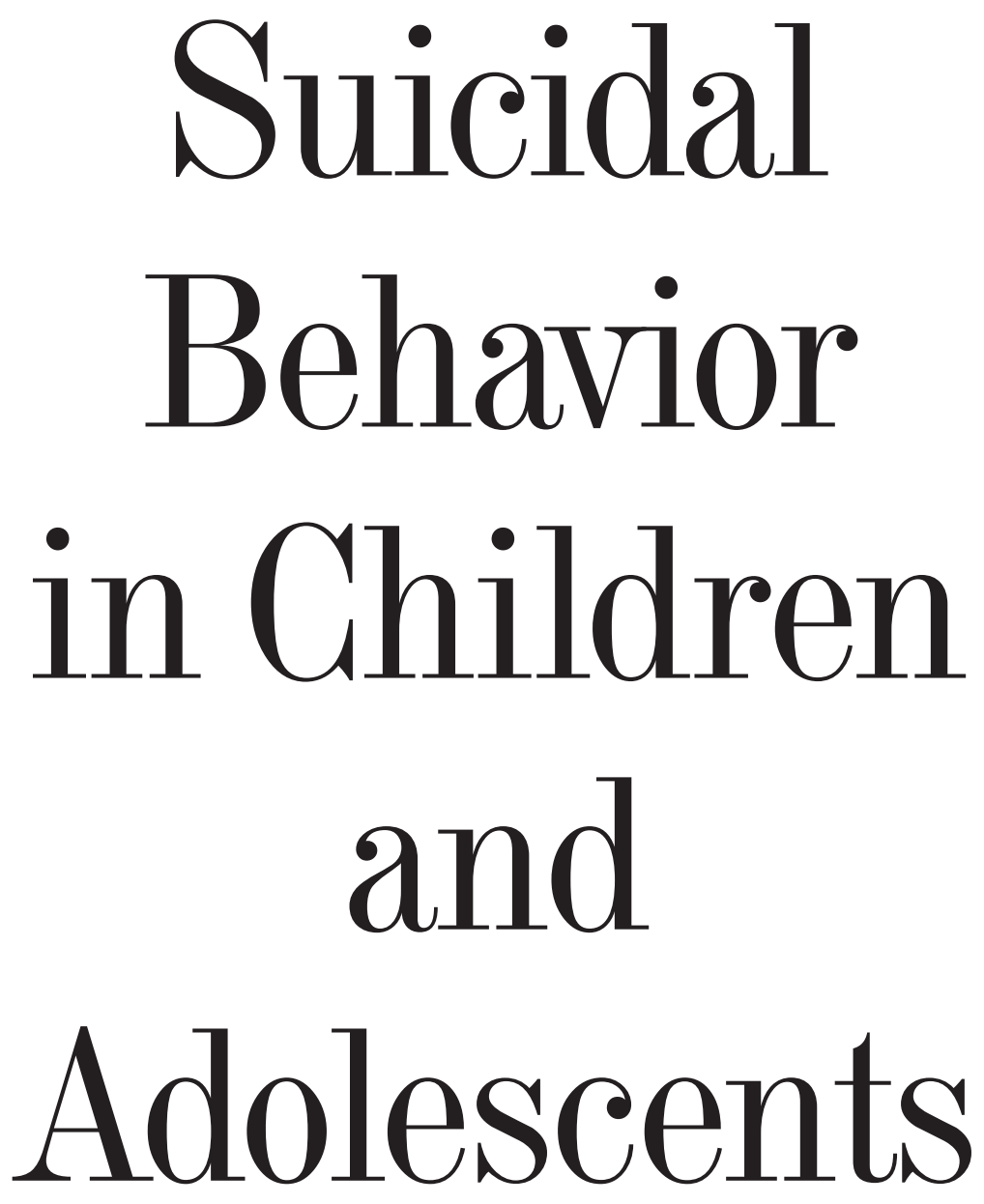

\section{Barry M.Wagner}


Copyright (C) 2009 by Yale University.

All rights reserved.

This book may not be reproduced, in whole or in part, including illustrations, in any form (beyond that copying permitted by Sections 107 and I08 of the U.S. Copyright Law and except by reviewers for the public press), without written permission from the publishers.

Set in Adobe Garamond by IBT Global.

Printed in the United States of America by IBT Global.

Library of Congress Cataloging-in-Publication Data

Wagner, Barry M.

Suicidal behavior in children and adolescents / Barry M. Wagner.

p. cm. (Current perspectives in psychology)

Includes bibliographical references and index.

ISBN 978-0-300-II250-4 (pbk. : alk. paper) I. Teenagers-Suicidal behavior-

United States. 2. High school students-Suicidal behavior-United States.

3. Suicide-United States. I. Title.

HV6546. W34 2009

$618.92 ' 858445-\mathrm{dc2} 2$

20090056 I 5

A catalogue record for this book is available from the British Library.

This paper meets the requirements of ANSI/NISO Z39.48-1992 (Permanence of Paper).

IO $98765432 \mathrm{I}$ 
To Julia 
This page intentionally left blank 